\title{
Foreign Aid Allocation from a Network Perspective: The Effect of Global Ties
}

\author{
Liam Swiss \\ Associate Professor \\ Department of Sociology \\ Memorial University \\ St. John's, NL, Canada A1C 5S7 \\ lswiss@mun.ca
}

This is a preprint version of an article forthcoming in Social Science Research.

\begin{abstract}
This article examines competing explanations for foreign aid allocation on the global level and argues for a new approach to understanding aid from an institutionalist perspective. Using network data on all official bilateral aid relationships between countries in the period from 1975 through 2006 and data on recipient country ties to world society, the article offers an alternative explanation for the allocation of global foreign aid. Fixed effects negative binomial regression models on a panel sample of 117 developing countries reveal that global ties to world society in the form of non-governmental memberships and treaty ratifications are strong determinants of the network centrality of recipient countries in the global foreign aid network. Countries with a higher level of adherence and connection to world society norms and organizations are shown to be the beneficiaries of an increased number of aid relationships with wealthy donor countries. The findings also suggest that prior explanations of aid allocation grounded in altruist or realist motivations are insufficient to account for the patterns of aid allocation seen globally in recent years.
\end{abstract}

Keywords: Foreign Aid; World Society; Network Analysis; Human Rights; Civil Society

Acknowledgements: This research was supported by the Social Science and Humanities Research Council of Canada. 


\section{Foreign Aid Allocation from a Network Perspective: The Effect of Global Ties}

\section{Introduction}

Why do some countries receive more aid than others? How do donors make decisions about how their foreign aid is allocated? Does aid make a difference? These questions have preoccupied social scientists studying the topic of foreign aid for much of the past half-century. Past research on foreign aid has tended to ask questions like why wealthier nations provide aid to developing nations, whether aid contributes to development in recipient countries, and, if not, how aid can be made more effective. This article offers a novel perspective on the question of why countries provide aid, while leaving the latter questions to other researchers. In particular, this article examines whether competing perspectives on the motivations behind aid allocation are sufficient explanations, and whether the promotion of world polity models, norms, and institutions may serve as an additional motivation for donors. If this motive underpins donor aid allocation, then we would expect to see more aid being allocated to more globally embedded recipients by more donors.

To test this hypothesis, this article asks: Do countries with a more ties to networks of global norms and international organizations receive aid from more donors? Are countries more embedded in world society also more central to the global foreign aid network? By testing three competing motives for the provision of aid, this article answers these questions using network data on aid relationships and demonstrates the importance of recipient country global ties as a determinant of aid allocation. I model aid network centrality counts in 117 developing countries over the period from 1975 through 2006 using fixed effects negative-binomial regression to test 
the effects of these competing motives on aid allocation. Results reveal that higher levels of global ties - operationalized as human rights treaty ratifications and international nongovernmental organization memberships - are associated with a higher degree of aid network centrality for recipient countries net of other controls and the institutionalization of the aid network over time. Further analysis reveals, perhaps counterintuitively, that developing countries more 'plugged in' to the global system of international actors and norms receive less aid per capita than others, but do so from a greater number of donors. This contradiction in aid allocation underscores the need for researchers to consider bilateral aid relationships as more than simple financial transfers through which 'development' is spread (Swiss 2016; Swiss and Longhofer 2016). Instead, my findings support an interpretation of aid relationships between countries as a network lattice dependent on shared global norms, policy models, and organizational membership to that underscore the relationships between countries, the organizations that implement aid, and the societies that mutually benefit.

The primary contributions of this article are twofold. First, by demonstrating that existing perspectives on the motives behind aid allocation are inadequate to explain aid allocation patterns, I highlight the need for researchers to take seriously world society embeddedness as a determinant of bilateral aid allocation. Second, by adopting an approach which examines aid allocation not as a counting of how much aid is transferred in dollar terms, and instead focuses on network centrality - the number of donor countries providing aid to recipients - I demonstrate the advantages of understanding aid as more than a financial transaction and treating it as a relational social network process between states (Peterson 2014; Swiss 2016). Both contributions advance the understanding of bilateral aid as a transnational process linked to 
globalization and casts a sociological light on a topic that has been dominated in past research by economists and political scientists.

\section{Background: The Distribution of Foreign Aid}

Bilateral aid is the official government-sanctioned development assistance provided by major western democracies to governments, NGOs, and other organizations in the developing world. In 2015, this type of aid amounted to more than $\$ 135$ billion USD even in the face of prolonged global financial struggles. Despite the fact that donors have repeatedly been encouraged to increase the size of projects and shrink the number of recipient countries in the name of effectiveness (Acharya, de Lima and Moore 2006; Annen and Kosempel 2009; Brown and Swiss 2013; Knack and Rahman 2007), aid is being provided to a greater number of countries and with smaller sized projects than ever before (Kilby 2011; Swiss and Brown 2015). The research literature on aid from the disciplines of economics and political science have conventionally offered two main interpretations for why countries provide aid: (1) aid is provided to fight poverty and promote development in support of 'international humanitarianism' (Lumsdaine 1993; Opeskin 1996); and (2) aid is provided to achieve donor national self-interest in foreign policy, trade, and other areas of donor priority (Alesina and Dollar 2000; Dreher, Nunnenkamp and Thiele 2011; Morgenthau 1962; Woods 2008). In contrast, little has been written exploring official development assistance as another form of transnational institution, one linked to supporting processes of globalization (Barrett and Tsui 1999; Fejerskov 2015; Jackson 2005; Peterson 2014; Swiss 2011; Swiss 2012; Swiss 2016; Swiss Forthcoming; Swiss and Longhofer 2016). This article explores this latter perspective as a test of the competing explanations for why and to where bilateral foreign aid is provided. Before exploring this perspective in greater 
depth, a brief review of the humanitarian and realist points of view is in order, as each motive is can yield different outcomes for where donors are most likely to concentrate their aid.

\section{Altruistic Motives: International Humanitarianism}

The international humanitarian approach suggests that donor countries' foreign aid decisions are motivated by a sense of 'moral vision' or humane altruism (Lumsdaine 1993; Opeskin 1996). In this respect, donors are seen to work in solidarity with recipients to try and resolve humanitarian crises and combat poverty. The grounding of aid in this altruistic base links modern-day aid relationships between states to concepts of charity and redistribution associated with western liberal Christian traditions. If we take for granted that aid is motivated by these humanitarian/altruistic aims, we should expect to see aid concentrated in the poorest countries and devoted to assisting the most marginal groups in the global context. As such, countries with low levels of per capita national income and other relevant markers of poverty would be seen as the prime recipients of bilateral foreign aid. Given this, in my analysis I expect that aid network ties will be more concentrated in countries with lower GDP per capita, those countries which are more impoverished. More recent evidence suggests that this is not always the case in reality. Wilson, for example, find that aid to health sectors tends to flow to those countries showing the best improvement in health measure rather than those in most need (2011). Evidence of this sort suggests that aid is not motivated purely by international humanitarianism, requiring the assessment of alternate perspectives on why and where countries provide aid.

\section{Realist Motives: Donor Self-Interest}


Hans Morgenthau's seminal article on the politics of aid (1962) lays plain the argument that bilateral foreign aid should be viewed as a tool of foreign policy wielded by wealthy countries to achieve their desired foreign policy and commercial outcomes. Later research expanded on this perspective and outlined how aid flows appear to follow patterns that support Morgenthau's contention (Alesina and Dollar 2000). Factors that have been shown to affect aid allocation include the importance of past colonial ties, democratic systems, existing trade relationships, geo-political importance, and efforts to combat state fragility/conflict (Bermeo 2011; Carment, Samy and Prest 2008; Feeny and McGillivray 2009; Hout 2002; Hout 2007; Hout 2012). The implications of donor self-interest as the primary motivation of aid are that we would expect to see aid concentrated in countries which are key commercial players on the global stage, have democratic systems of governance, and have past colonial relationships to donor countries. Furthermore, we might expect to see aid concentrated in states that have a recent experience of conflict or are newly independent, as donors rush to support fragile, post-conflict, or emerging states. Given these manifold possible measures of donor self-interest associated with the realist perspective, I expect in my analysis that aid network ties will be more concentrated in: countries where trade is a more central part of their economy; democratic regimes; and countries which have recently experienced conflict or are newly independent.

\section{Institutionalist Motives: Rewarding Global Ties}

Past research suggests that we can reasonably expect evidence of realist motivations for aid, but that in practice, donor motives are often a complex mix of altruism and realism. Pinning the motives of aid to a single underlying cause is therefore an oversimplification of a complex transnational process. For this reason, I aim in this article to elaborate on some of that 
complexity by focusing on aid as a transnational relationship rather than simply a financial transaction(Swiss 2016). This article argues that another facet of the aid allocation process worth considering is the role played by global ties to world society. If aid is a transnational and relational process rather than a simple financial transaction, it can embody and encourage norms of global good citizenship and legitimacy for countries. Meyer et al.'s (1997) fictionalized newly emerged state and its expected adoption of a wide array of world cultural norms, models, and institutions would, for instance, become a fitting recipient of bilateral foreign aid. Indeed, Meyer et al. argue that aid would help facilitate the integration of the new island nation into the global community.

Past research examining this idea that aid relationships follow a pattern which works to reinforce global norms and practices have focused on how aid is shaped by and shapes the networks and norms of world society. Donors show preference for recipient countries more plugged into networks of international organizations: Peterson (2011), for instance, revealed that countries with more memberships in international organizations were more 'attractive' recipients of donor aid. Swiss and Longhofer (2016) echo this finding by demonstrating that donors are more likely to provide aid to recipient countries with which they share common organizational memberships. Donors also show preference for countries adopting certain norms, policies, and organizational forms domestically: Barrett and Tsui (1999) argue that countries adopting national population policies received increased aid from USAID in comparison to countries that had no such policies. Schofer and Longhofer find that foreign aid is linked to an increased level of association formation within recipient countries (2011). Others have argued that NGOs and aid workers themselves can play a globalizing role or act as cosmopolitan conduits in recipient countries (Fejerskov 2015; Jackson 2005; Themnér and Wallensteen 2011). 
Beyond the adoption of one specific policy, this article tests the proposition that those countries more intimately embedded in world society are more likely to receive aid from a greater number of donors - no matter how little aid is actually provided. Embeddedness takes many forms, and past world society research has operationalized this concept in various ways including: national level memberships in international civil society organizations (Clark 2010; Hughes et al. 2009; Paxton, Hughes and Reith 2015; Swiss 2012; Swiss and Longhofer 2016), membership in intergovernmental organizations (Beckfield 2003; Beckfield 2008), centrality in telecommunications networks (Clark and Hall 2011) and even through countries' ratification of human rights treaties (Clark 2010; Cole 2012; Cole 2013; Fallon, Swiss and Viterna 2012; Hafner-Burton and Tsutsui 2005; Wotipka and Ramirez 2008). If institutionalist motives are found to influence the provision of aid by more donors, then I expect to see aid network ties increase in countries that have a higher level of embeddedness in world society measured by human rights treaty ratifications and international non-governmental organization memberships.

\section{Foreign Aid as a Global Network}

Aid allocation has been measured in various ways in past research: total dollars of aid, aid per capita, aid as a percentage of GDP, aid as a percentage of a donor country's total aid envelope. Each of these focuses on aid allocation as being grounded in the question of 'how much' aid is allocated, rather than whether any official aid relationship exists. In this article I adopt a network approach to understanding aid allocation by focusing not on the question of how much aid is provided, but instead on the question of how many donor countries does a recipient country have aid ties with. This distinction, though slight, treats aid between countries not as a financial 
transaction, but as a broader transnational social relationship between states (Swiss 2016; Swiss Forthcoming). From this perspective, the amount of aid flowing between countries matters less than the fact that there is any aid relationship at all. Employing a global aid network dataset that tracks recipient centrality as the count of how many donor countries from which they receive aid refocuses our question of how aid is allocated not on which countries receive the most aid, but instead on which countries receive aid from a larger proportion of the global donor community. Little past research has adopted this approach (Moore, Eng and Daniel 2003; Peterson 2011; Swiss Forthcoming; Swiss and Brown 2015), but by applying social network analysis techniques to the bilateral relationships embodied in the aid process, achieving a new picture of aid allocation is possible.

\section{Data and Method}

\section{Sample}

The sample for my analysis consists of 117 aid recipient countries from the period of 1975 through 2006. ${ }^{1}$ Countries are included in the sample in every year for which data is available for all covariates, creating an unbalanced annual panel dataset. Countries with missing data are removed via casewise deletion. Countries that become newly independent are included only for those years following independence. This sample thus includes most, but not all countries that received bilateral aid in this period from the group of OECD DAC donors. Included in the sample are several countries that move from receiving aid to becoming aid donor countries themselves: Republic of Korea and Turkey are examples here.

\footnotetext{
${ }^{1}$ The countries included in the sample are shown in the table in Appendix 1.
} 


\section{Dependent Variables}

Measures of aid allocation by recipient countries have in previous research been operationalized as either aid per capita, total aid volumes, or aid as a percentage of national income. This article's innovation is to conceive of bilateral foreign aid as a bimodal relational network on the global scale and to measure aid allocation via in-degree aid network centrality. ${ }^{2}$ In simple terms, this measure consists of the number of donors from which a country receives bilateral ODA. Using OECD statistics on ODA flows, I compiled a network dataset of all bilateral aid ties from 1960 through 2008. In the analyses that follow, all other covariates are lagged behind the dependent variables by 2 years, allowing for temporal precedence and the potential for various covariates to influence aid allocation decisions. Hence, for the 1975 observation year, the aid network centrality measure is for 1977 . In this respect, the aid network measures cover the period from 1977 through 2008.

I include two separate aid network measures in the analysis. First, I calculated aid network centrality for all reported bilateral ODA ties between countries. This measure should reflect all officially reported aid ties of any level, ranging from very small amounts to much larger aid flows. Over the period of my study, the median network centrality measure for my sample of 117 countries ranges from 11 in 1977, doubling to 22 in 2008. This doubling of the median number of donor countries reflects the institutionalization of foreign aid over this period with a rapid expansion in both donors and recipients. As Figure 1 indicates, in 1975 countries tended to receive aid from fewer countries than in 2005, reflecting the institutionalization of aid as a global

\footnotetext{
${ }^{2}$ Other aid network research has also used eigenvector centrality, but in this case, a simpler understanding of network centrality as a raw count of donors is preferred when using a bimodal network matrix.
} 
process. This expansion of the global aid network is seen at the individual country level in the summary statistics of the aid network centrality and aid per capita measures in Appendix 1.

\section{[FIGURE 1 ABOUT HERE]}

Second, to account for the relative impact of aid dollars, I include an aid network centrality measure for only those aid ties in excess of $\$ 1$ million in current dollar terms. This alternate measure should reflect only that aid which can be deemed non-trivial, and would likely exclude small financial transfers sometimes counted as aid like scholarships and small funds administered by donor embassies in the Global South. Comparing Figures 1and 2 reveals that in both 1975 and 2005 a smaller number of countries receive aid from donors in excess of \$1 million. The median aid ties greater than \$1 million was 5 in 1975, climbing to 11 in 2005 . This difference in all aid ties and more substantial aid ties is indicative of the fact that many aid donor countries tend to provide small amounts of aid to developing countries as a courtesy or for reputational reasons. Notable, also, in Figure 2 are a small number of countries which are focal points for aid where the number of aid ties in excess of one million is high and approaches the level of all aid ties. For some smaller countries with relatively low number of aid donors, the difference between all ties and ties exceeding $\$ 1$ million is zero or one, implying that though they receive aid from few donors, that aid exceeds the threshold set here for substantial aid.

\section{[FIGURE 2 ABOUT HERE]}




\section{Independent Variables}

Global Ties: This article tests whether countries with stronger ties or embeddedness in world society institutions and networks are likely to receive aid from more donors. To control for these global ties, I include two primary measures of world society embeddedness.

The first measure of global ties is an annual count of human rights treaties ratified by each country. This count measure ranges from zero to six and includes each of the primary United Nations human rights treaties and covenants. ${ }^{3}$ Countries which have ratified a greater number of the treaties reflect those countries which have more fully adopted the human rights institutions promoted by world culture proponents, and thus those countries which are more closely tied to world society. The median number of ratifications for my sample countries over the entire study period is four, but ranges from one in $1975(\mathrm{n}=79)$ to six in $2006(\mathrm{n}=102)$.

The second global ties measure is a count of country-level memberships in International NonGovernmental Organizations or INGOs drawn from Union of International Association data. ${ }^{4}$ The INGOs memberships count is intended to reflect the ties of a country to the nongovernmental organizations and networks that comprise world society's 'rationalized others' (Meyer et al. 1997). The greater the number of memberships, the more embedded or connected a country is to world society. In the study sample, the median number of memberships over the 1975-2006 period is 335. This median value grows from 106 in 1975 to over 515 in 2006 . The

\footnotetext{
${ }^{3}$ Including: International Convention on the Elimination of All Forms of Racial Discrimination (ICERD); International Covenant on Civil and Political Rights (ICCPR); International Covenant on Economic, Social and Cultural Rights (ICESCR); Convention on the Elimination of all forms of Discrimination Against Women (CEDAW); Convention against Torture and Other Cruel, Inhuman or Degrading Treatment or Punishment (CAT); and the Convention on the Rights of the Child (CRC).

${ }^{4}$ Thanks to Wesley Longhofer for sharing this data.
} 
Other Aid Motivations: The other independent variables included in this analysis mirror the two broad categories of aid motivations outlined earlier: (1) socio-economic/humanitarian need; and (2) realist donor/geo-political interests.

Socio-Economic Status: To account for socio-economic factors, three measures are included in the models: GDP per capita (constant 2005 dollars); population (millions); and goods and services exports as a percentage of GDP. GDP per capita is a frequently used measure of overall economic development of a nation, though it fails to account for the distribution of national income within society and discrepancies in cost of living. The country's population is also included in the models as there is evidence suggesting that bilateral aid tends to flow to countries with larger populations. Both the GDP per capita and population measures are drawn from the Penn World Tables dataset (Heston, Summers and Aten 2011). Data on goods and services exports as percentage of national income is included to account for the influence of trade on donor aid allocation. ${ }^{5}$ Countries where goods and services exports comprise a greater share of national income are likely those countries for which international trade is a key component of their development. Donors are more likely to provide aid to trade partners than to non-trading nations. It is expected that countries with exports as a higher share of national income will attract aid from more donors. Data on goods and services exports is drawn from the World Bank’s World Development Indicators dataset (World Bank 2010).

Geo-Politics and Donor Foreign Policy Interests: Donor foreign policy and international geopolitical interests also influence aid allocation. In the past, donors have been shown to provide

\footnotetext{
${ }^{5}$ This trade measure would best be captured in a dyadic form, but given the cross-national rather than dyadic nature of this study, it is beyond the scope of the present analysis to examine the influence of dyadic trade relationships on aid ties.
} 
more aid to: democratic regimes, countries with colonial ties to the donor, post-conflict countries, and newly independent countries. I include several measures to account for these donor and international political interests.

First, I include a categorical measure of democratic transition which accounts for the timing of transition and the type of previous situation from which a country transitions: civil strife, authoritarian regime, or Communism. This measure accounts for all post-1975 democratic transitions and is derived from Fallon, Swiss, and Viterna (2012). In my sample, 53 of 123 countries experience democratic transition in the 1975 to 2006 period, with 10 transitioning from civil strife, 31 from authoritarian regimes, and 12 from Communism. The reference category is no transition. I also include a measure of democratic quality via the often-used Polity IV score (Marshall, Jaggers and Gurr 2009). Where Polity scores were not available, I substituted alternate Polity IV measures as developed by Gerring, Thacker, and Moreno (2005). The median Polity score for my sample countries in $1975(\mathrm{n}=82)$ was -7 . In 2006, this same median score is $5(\mathrm{n}=115)$. This shift in average democratic quality of more than 12 points over the course of the study period indicates the extent of democratization in the developing world in this time.

In addition to these democratization measures, I include dummy variables for colonial history, the presence of intrastate conflict, and the timing of independence. Colonial history is coded as a one if the country was colonized previously. The conflict dummy variable is coded as a one for countries which experienced any intrastate conflict in that year according to the UCDP/PRIO Intrastate Conflict Database (Gleditsch et al. 2002). Finally, a dummy variable is included for 
the five years post-independence to account for any influx of donor funds to newly independent countries.

Institutionalization of the Global Aid Network: To account for the growth and rapid expansion of the global aid network over time, I include a categorical time measure by decade. This accounts for the average donor indegree centrality in each decade and controls for the time trend evident in the data. Four categories are included: 1970s (reference category); 1980s, 1990s, and 2000s.

\section{Method}

To model bilateral aid network centrality data over time, I treat network centrality as a simple count of aid ties and use a fixed effects negative-binomial regression approach suitable to count data (Rabe-Hesketh and Skrondal 2008). Fixed effects models were selected rather than random effects models after comparing the results of both using a Hausman specification test. The results of the models are reported as exponentiated coefficients, or incidence rate ratios (count ratios) which enables the prediction of percentage change in aid network centrality counts with each corresponding change in continuous covariates or between different categorical measures (Rabe-Hesketh and Skrondal 2008) Following Gelman (2008), all continuous independent variables are scaled before inclusion in models by dividing by twice their standard deviation to permit easier comparison using low-high scale similar to a binary measure. ${ }^{6}$

\section{[TABLE 1 ABOUT HERE]}

\section{Results}

\footnotetext{
${ }^{6}$ The incident rate ratios (IRR) for these variables thus represent the effect of a two standard deviation change in any given measure on the count of donors a country is predicted to have aid relationships with.
} 


\section{All Aid Network Ties}

Table 1 reports the results of negative binomial regression of foreign aid network centrality on the independent variables that are the focus of this study. ${ }^{7}$ Model 1 includes socioeconomic factors including aid per capita, GDP per capita, population, and goods and service exports as a percentage of GDP. As aid per capita increases, there is a slight decrease in the number of donors (-4\%). GDP per capita shows no significant effect on aid ties, while both population and goods and services exports yield increases to aid network centrality of $78 \%$ and $23 \%$ respectively. These results suggest that donors are more likely to strike up aid relationships with more populous countries that rely more heavily on goods and services exports to drive their economies - providing support for the realist perspectives on aid. The effect of GDP per capita, on the other hand, offers no support for the humanitarian perspective that donors are more likely to aid poorer countries.

In Model 2, I introduce the Polity IV score to account for level of democracy. A two standarddeviation improvement in democratic quality yields a more than $30 \%$ increase in aid network centrality, suggesting that donors do, in fact, prefer to maintain aid relationships with more democratic nations.

Models 3 and 4, introduce dummy variables accounting for conflict and timing of independence. Only independence timing shows a significant relationship, and contrary to expectations, indicates a reduced centrality count for countries in their first five years of independence, with $23 \%$ fewer donors on average than after the five-year post-independence period.

\footnotetext{
${ }^{7}$ The incident rate ratios for all continuous measures reflect a two standard deviation change in that variable, so in the description of the results that follow I will simply refer to increased or decreased amounts of those variables as shorthand for that two standard deviation change.
} 
Models 5 and 6 adds the measures for global ties. In my sample of 117 countries, a two-standard deviation increase in INGO memberships amounts to approximately 742 additional NGO memberships, which is predicted to yield $71 \%$ more donor ties in Model 5. Human rights treaty ratifications are also associated with increased network centrality in Model 6. Each additional two treaty ratifications predict an increase in a country's centrality count of $36 \%$. Overall, the results for both measures of global ties support my hypothesis that greater embeddedness in world society contributes to increased donor attention and a greater number of bilateral aid ties. Of note, when either world society measure is incorporated in the analysis, the effects of GDP per capita become statistically significant and show a decrease of either 27 or 12 percent in Models 5 and 6 respectively. This suggests support for the humanitarian motives of aid - donors are less likely to maintain aid ties with a country as their level of GDP per capita increases.

Model 7 displays results of the full model. Notable differences in comparison to earlier models include: (1) the effects of goods and services exports are no longer statistically significant; (2) the effect of both GDP per capita and population are shown to reduce aid ties; and (3) the effects of an increase in the level of democracy are reduced from a $31 \%$ increase in aid ties to an only $10 \%$ increase. The direction and general magnitude of the effects of all other covariates is more or less unchanged. The effects of global ties remain significant at the $p<0.001$ level, though the magnitude of the rate ratios for each measure is reduced slightly. Notably, both the INGO memberships and treaty ratifications are the two variables with the strongest positive effect on aid ties, and a two standard deviation increase in INGO memberships has the largest effect (positive or negative) of any of the standardized variables in the model. 


\section{[TABLE 2 ABOUT HERE]}

\section{All Aid Network Ties $>\$ 1$ million}

Table 2 reflects analysis identical to those captured in Table 1 with the second dependent variable: aid ties greater than $\$ 1$ million in current dollar terms. The patterns evident in the table largely mirror Table 1, indicating that more substantial aid ties between donor and recipient are subject to the same influences as smaller ties.

The global ties measures in the second analysis are consistent with the results reported in Table 1, with an increased positive effect of both INGO memberships and treaty ratifications in Model 7. Using a network measure of ties over $\$ 1$ million shows that the effects of human rights treaties and NGO memberships found when considering all aid network ties are robust to a specification which limits the definition of aid to more substantial flows of funds. In Model 7 a two standard deviation increase in INGO memberships is predicts a $30 \%$ increase in aid ties, while increased treaty ratifications are associated with a $53 \%$ increase in ties.

Overall, these results suggest that when examining the motivations of donors and the corresponding allocation of aid, we must take into consideration the effect of recipient country global ties alongside other concerns like international humanitarianism or donor self-interest. The robust, relatively large, and significant effect of both INGO memberships and treaty ratifications on the number of overall aid ties, as well as on a reduced sample of aid ties greater than $\$ 1$ million, shows that the motives underpinning aid allocation are more complex than either 
the realist or humanitarian perspectives can account for. Why this is a significant innovation to our understanding of the allocation of bilateral aid is discussed more fully in the next section.

\section{Discussion}

The results outlined above provide compelling evidence that the motives for aid are complex and overlapping. Altruist, realist, and institutionalist motives are evident in my results, but not in a consistent and robust fashion. No one perspective accounts best for the allocation of aid. To be sure, realist and humanitarian arguments are supported in my results. Poorer countries have a greater number of aid ties. Countries receiving a greater amount of aid per capita are more likely to have a larger number of aid ties. Still, the consistent and robust finding of a positive relationship between world society embeddedness and aid ties speaks to something else that merits attention beyond the realist and humanitarian perspectives.

The evidence for the realist perspective in my results is mixed. Countries with a higher level of trade in goods and services at the centre of their economy are predicted to have more aid ties. Although this can indicate that commercial motives affect donor aid allocation decisions, without country-to-country dyadic trade data it may also be interpreted as support for a global ties hypothesis in that countries with increasing ties to the global trade network are predicted to receive aid from more donors. Indeed, though Swiss and Longhofer (2016) show that donors are more likely to provide aid to countries with which they trade, the amount of aid provided is not associated with the extent of trade. Likewise, no consistent evidence is offered for realist arguments that countries are likely to receive aid from more donors when newly independent. One area that does not appear to match previous arguments in realist perspectives is the seeming 
withdrawal of donors from more established democracies. My results show that rather than democracy attracting more donor ties, the opposite effect holds. In sum, my results suggest that the realist motives for aid provision are a plausible but insufficient explanation for where donors choose to build transnational aid relationships. Realist explanations do not, for instance, explain why donors would maintain aid ties with geopolitically or commercially unimportant aid partners that are neither former colonies nor in great need in terms of poverty - countries like Namibia or Angola are examples that might fit these criteria.

To complement these other motives, my analysis suggests we need to account for the extent to which donors channel their aid to countries which are viewed as being more 'plugged in' to world society. Those countries which are deemed good global citizens in that they sign on to the full array of global human rights treaties and have citizens involved with a higher number of international non-governmental organizations appear to be accorded preferential treatment by a higher number of donors. Recipient countries which meet the criteria of a higher number of global ties are likely to reap the benefits of having a more diverse group of donor with which to engage to support their development.

This begs the question of whether these ties lead to greater amounts of aid, if we adopt a more conventional focus on aid as volume of funds. Additional analysis ${ }^{8}$ on the relationship between global ties and levels of aid per capita reveals that the total amount of aid per capita a country receives deceases when it receives aid from more donors. Random effects panel regression results show that the same two standard deviation increase in INGO memberships is predicted to

\footnotetext{
${ }^{8}$ Available upon request.
} 
reduce aid per capita to a country by approximately $\$ 25$ per capita, all else equal over the period of my analysis. This suggests that world society ties held by developing countries do not necessarily contribute to higher levels of overall aid funding, but do yield a higher number of global aid network ties. This finding offers compelling support for the innovation offered in this paper to look at aid allocation from a network perspective. Relationally, countries reward developing countries by maintaining formal aid ties, even if the overall levels of aid to those countries are reduced. This enables donors to maintain the reputation as aid providers in a country while not devoting substantial resources to the relationship - a token amount of aid in this respect may simply allow local donor diplomats to fund worthy activities in line with their donor interests and/or development requirements of the partner state. Conversely, recipient countries may have incentives to attract aid from a larger number of donors - despite the possibility of smaller amounts of aid dollars - to better cement their global reputations as legitimate states and further their enactment of various world society norms and policy prescriptions. This suggests that the bilateral aid relationship between countries is about more than simply the overall flow of funds between the countries - a topic that merits further investigation in the research on aid.

Independent of how much aid countries receive in dollar terms, countries with a higher level of engagement on the global stage can expect a higher degree of aid network centrality, net of their national income status, reliance on trade, systems of governance, and recent history of conflict or independence. This finding expands on Barrett and Tsui's (1999) earlier research suggesting that certain policies were rewarded with additional American bilateral aid funds, and complements Peterson's (2011) and Swiss and Longhofer's (2016) findings regarding the link between 
organizational memberships and the "attractiveness" of recipient countries to donors. By demonstrating that recipient countries position vis-à-vis the norms and organizations that comprise world society has a direct effect on the number of other countries which choose to engage them in the process of development assistance, this article makes a contribution to a more nuanced understanding of aid allocation. More importantly, it raises a new direction for research that focuses less on the effects of more aid by volume, and more on the effects of the transnational relational process of maintaining aid ties despite their potentially dwindling size. Indeed, despite exhortations by the OECD DAC and the international aid effectiveness agenda to focus donor efforts and reduce the total number of aid recipients while increasing overall aid budgets, evidence shows that donor countries are choosing instead to maintain aid ties to a large numbers of recipients (Brown and Swiss 2013). Future research should examine more closely this phenomenon of why donors are keen to maintain aid ties in spite of declining aid volumes how such ties are motivated by a recipient country's embeddedness in world society.

Although considering only global level network data and macro level global tie measures that are not broken down by sector, this article yields new insights into how donor countries allocate their aid. Advances in the granularity of aid data that have recently emerged will enable future research to examine this relationship between global ties and aid network centrality in more specific contexts at the global level. For instance, future research might inquire whether a greater number of ties to Women's International Non-Governmental Organizations (WINGOs) is associated with more donors providing aid in the areas of gender equality and women's rights. For now, the innovation here of using rudimentary social network analysis to examine aid allocation are hampered by the inability to accurately track aid dollars in specific sectors over the 
long-term and to match them to world polity model/norm adoption in those same sectors. One would expect, however, that in the future, such analysis will be possible with a broad population of donors as more donor countries sign on to the International Aid Transparency Initiative and as alternate sources of aid donor information, like AidData.org's dataset, mature.

The competing motives for aid allocation at the global level are clearly overlapping and difficult to disentangle. The complexity associated with this transnational development process and its links to processes beyond solidarity, trade, and geo-politics is something this article makes plain. The conventional motives for aid clearly are incomplete, and future research on bilateral aid needs heed earlier calls (see: Peterson 2014 and Swiss 2016) to take more seriously the role aid plays in promoting globalization through rewarding countries more intimately embedded in the networks and norms of world society. 
Table 1. Fixed effects negative-binomial panel regression of aid network centrality (all ties), 1975-2006

\begin{tabular}{|c|c|c|c|c|c|c|c|}
\hline & $(1)$ & $(2)$ & $(3)$ & $(4)$ & $(5)$ & $(6)$ & $(7)$ \\
\hline \multicolumn{8}{|l|}{ CONTROLS } \\
\hline \multicolumn{8}{|l|}{ Decades } \\
\hline $1970 \mathrm{~s}$ & 1 & 1 & 1 & 1 & 1 & 1 & 1 \\
\hline $1980 \mathrm{~s}$ & $3.45^{* * *}$ & $3.39^{* * *}$ & $3.36^{* * * *}$ & $3.45^{* * *}$ & $3.13^{* * *}$ & $2.89^{* * * *}$ & $2.55^{* * *}$ \\
\hline $1990 \mathrm{~s}$ & $3.96^{* * *}$ & $4.06^{* * *}$ & $3.84^{* * * *}$ & $3.96^{* * *}$ & $3.34^{* * *}$ & $2.75^{* * * *}$ & $2.42^{* * *}$ \\
\hline $2000 s$ & $4.33^{* * *}$ & $4.52^{* * * *}$ & $4.22^{* * *}$ & $4.32^{* * *}$ & $3.49^{* * *}$ & $2.77^{* * *}$ & $2.45^{* * *}$ \\
\hline Aid per capita & $1.23^{* * *}$ & $1.23^{* * *}$ & $1.23^{* * *}$ & $1.23^{* * *}$ & $1.23^{* * *}$ & $1.23^{* * * *}$ & $1.23^{* * *}$ \\
\hline GDP per capita & $0.85^{* * *}$ & $0.84^{* * *}$ & $0.86^{* * *}$ & $0.85^{* * *}$ & $0.73^{* * *}$ & $0.86^{* * *}$ & $0.76^{* * *}$ \\
\hline Population (millions) & $1.41^{* * *}$ & $1.39^{* * * *}$ & $1.38^{* * *}$ & $1.41^{* * * *}$ & 1.10 & $1.41^{* * *}$ & 1.11 \\
\hline Goods and services exports & $1.80^{* * *}$ & $1.80^{* * *}$ & $1.81^{* * *}$ & $1.80^{* * * *}$ & $1.84^{* * *}$ & $1.80^{* * *}$ & $1.83^{* * *}$ \\
\hline Polity IV score & & $0.86^{* * *}$ & & & & & $0.78^{* * *}$ \\
\hline Intrastate conflict (No) & & & 1 & & & & 1 \\
\hline Intrastate conflict (Yes) & & & $1.12^{* * *}$ & & & & $1.08^{* *}$ \\
\hline Post-independence period (No) & & & & 1 & & & 1 \\
\hline Post-independence period (Yes) & & & & 0.94 & & & 1.14 \\
\hline \multicolumn{8}{|l|}{ GLOBAL TIES } \\
\hline INGO memberships count & & & & & $1.45^{* * *}$ & & $1.36^{* * *}$ \\
\hline Human rights treaty ratifications & & & & & & $1.45^{* * *}$ & $1.47^{* * *}$ \\
\hline Observations & 3085 & 3085 & 3085 & 3085 & 3085 & 3085 & 3085 \\
\hline Countries & 117 & 117 & 117 & 117 & 117 & 117 & 117 \\
\hline Log-likelihood & -7577.3 & -7413.6 & -7576.7 & -7553.9 & -7263.8 & -7262.2 & -7195.7 \\
\hline AIC & 15162.7 & 14837.3 & 15163.4 & 15117.8 & 14537.6 & 14534.3 & 14409.3 \\
\hline
\end{tabular}

Incident rate ratios shown.

${ }^{*} p<0.05,{ }^{* *} p<0.01,{ }^{* * *} p<0.001$ (two-tailed test) 
Table 2. Fixed effects negative-binomial panel regression of aid network centrality (ties>\$1 million), 1975-2006

\section{CONTROLS \\ Decades \\ 1970s \\ $1980 \mathrm{~s}$ \\ $1990 \mathrm{~s}$ \\ 2000s}

Aid per capita

GDP per capita

Population (millions)

Goods and services exports

Polity IV score

Intrastate conflict (No)

Intrastate conflict (Yes)

Post-independence period (No)

Post-independence period (Yes)
(1)

(2)

(3)

$\begin{array}{ll}1 & 1 \\ 3.69^{* * *} & 3.65^{* * *} \\ 4.08^{* * *} & 4.16^{* * *} \\ 4.45^{* * *} & 4.61^{* * *} \\ 1.30^{* * *} & 1.30^{* * *} \\ 0.82^{* * *} & 0.81^{* * *} \\ 1.37^{* * *} & 1.36^{* * *} \\ 1.83^{* * *} & 1.83^{* * *} \\ & 0.89^{* *}\end{array}$

(5)

(6)

\section{GLOBAL TIES}

INGO memberships count

Human rights treaty ratifications

(4)

Observations

Countries

Log-likelihood

Incident rate ratios shown.

${ }^{*} p<0.05,{ }^{* *} p<0.01,{ }^{* * *} p<0.001$ (two-tailed test)

\begin{tabular}{ccccccc}
3085 & 3085 & 3085 & 3085 & 3085 & 3085 & 3085 \\
117 & 117 & 117 & 117 & 117 & 117 & 117 \\
-7642.6 & -7638.0 & -7637.8 & -7642.3 & -7624.8 & -7596.5 & -7571.4 \\
15299.2 & 15292.1 & 15291.6 & 15300.7 & 15265.5 & 15209.1 & 15166.9 \\
\hline
\end{tabular}

1

$2.79^{* * *}$

$2.49^{* * *}$

$2.48^{* * * *}$

$1.29^{* * *}$

$0.72^{* * *}$

1.14

$1.82^{* * *}$

$0.82^{* * *}$

1

$1.06^{*}$

1

1.15 
Figure 1. Aid Network Centrality by Country, 1975 and 2005

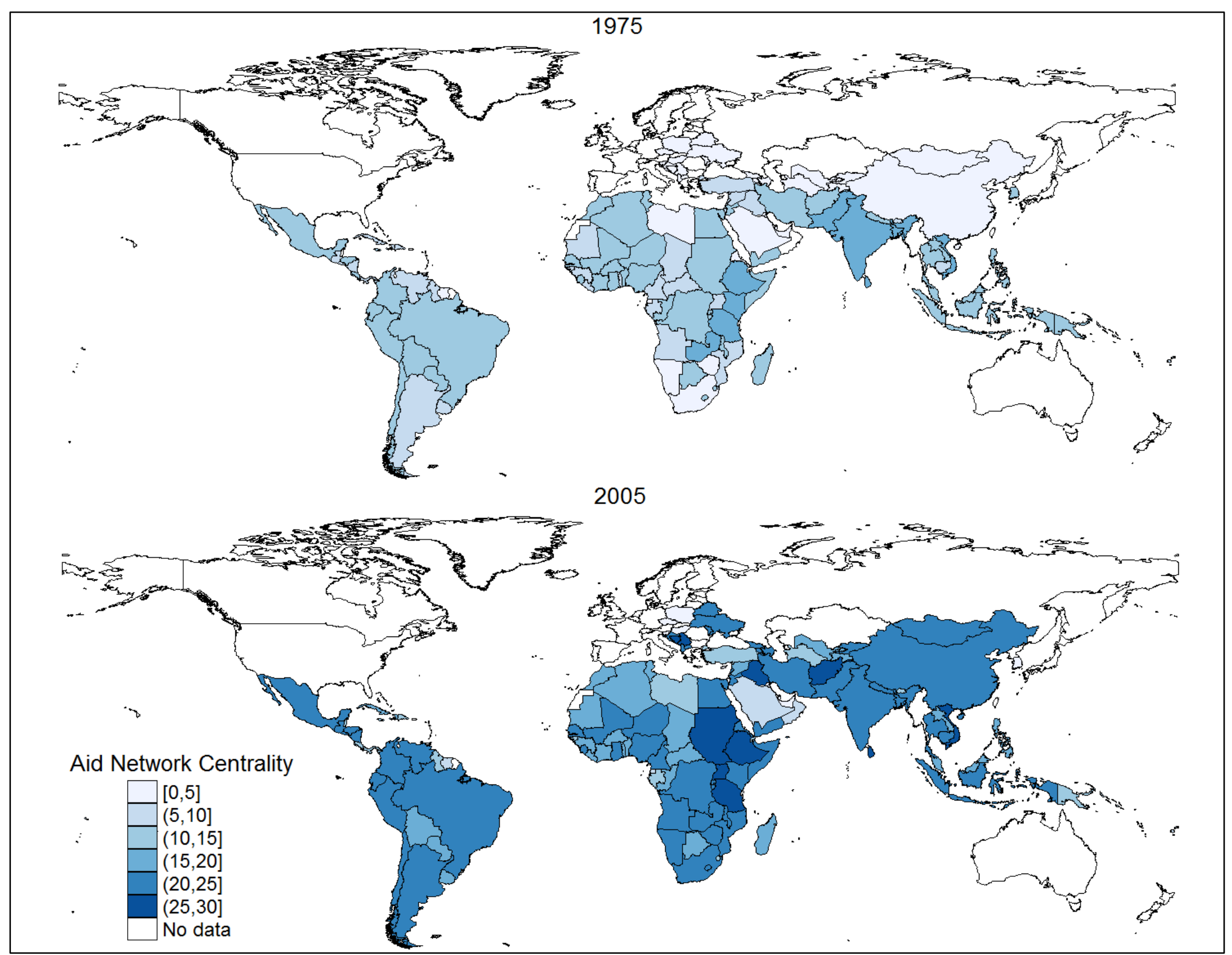


Figure 2. Aid Network Centrality (ties $>\$ 1$ million current dollars) by Country, 1975 and 2005

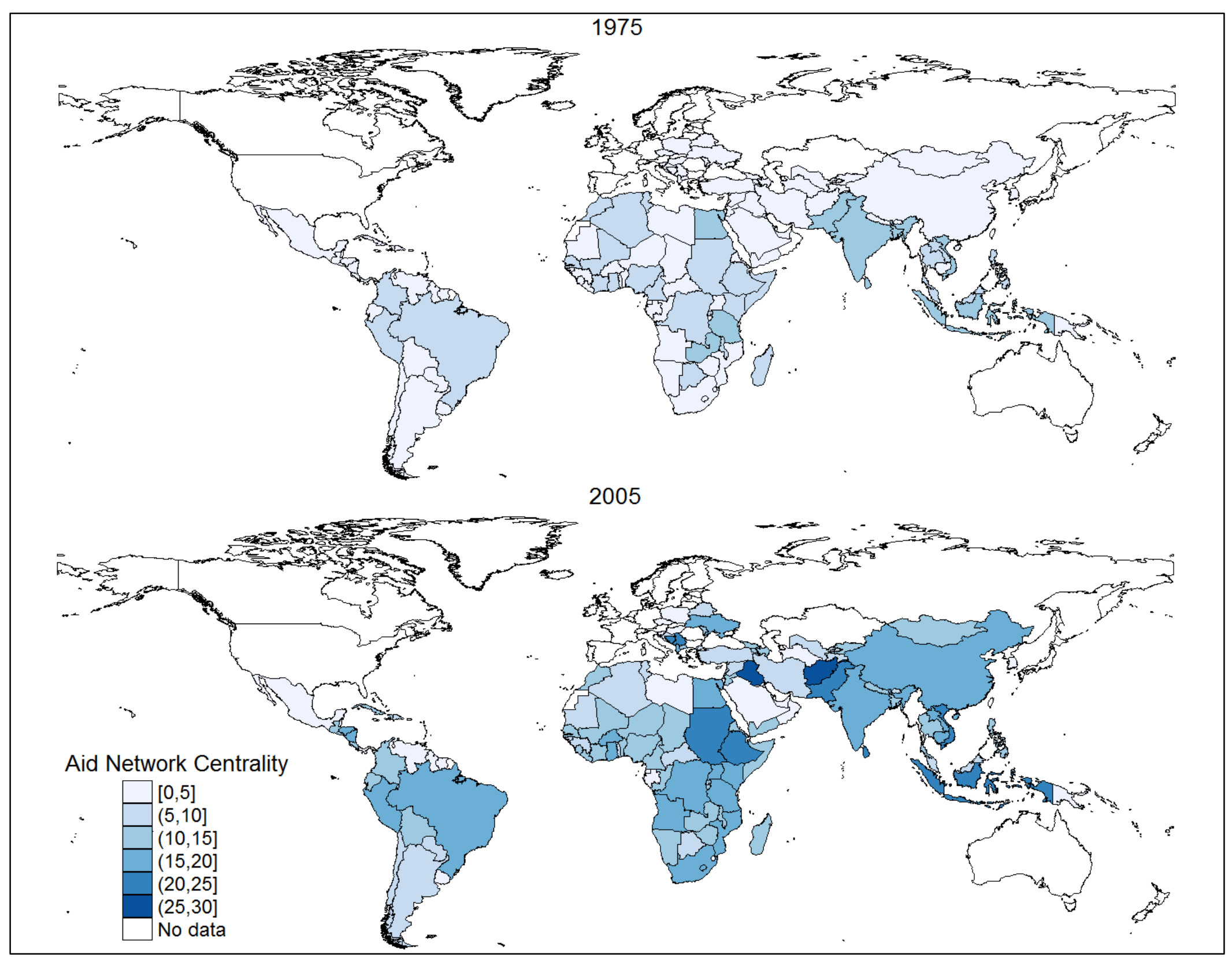


Figure 3. Incident Rate Ratios, Table 2, Model 7

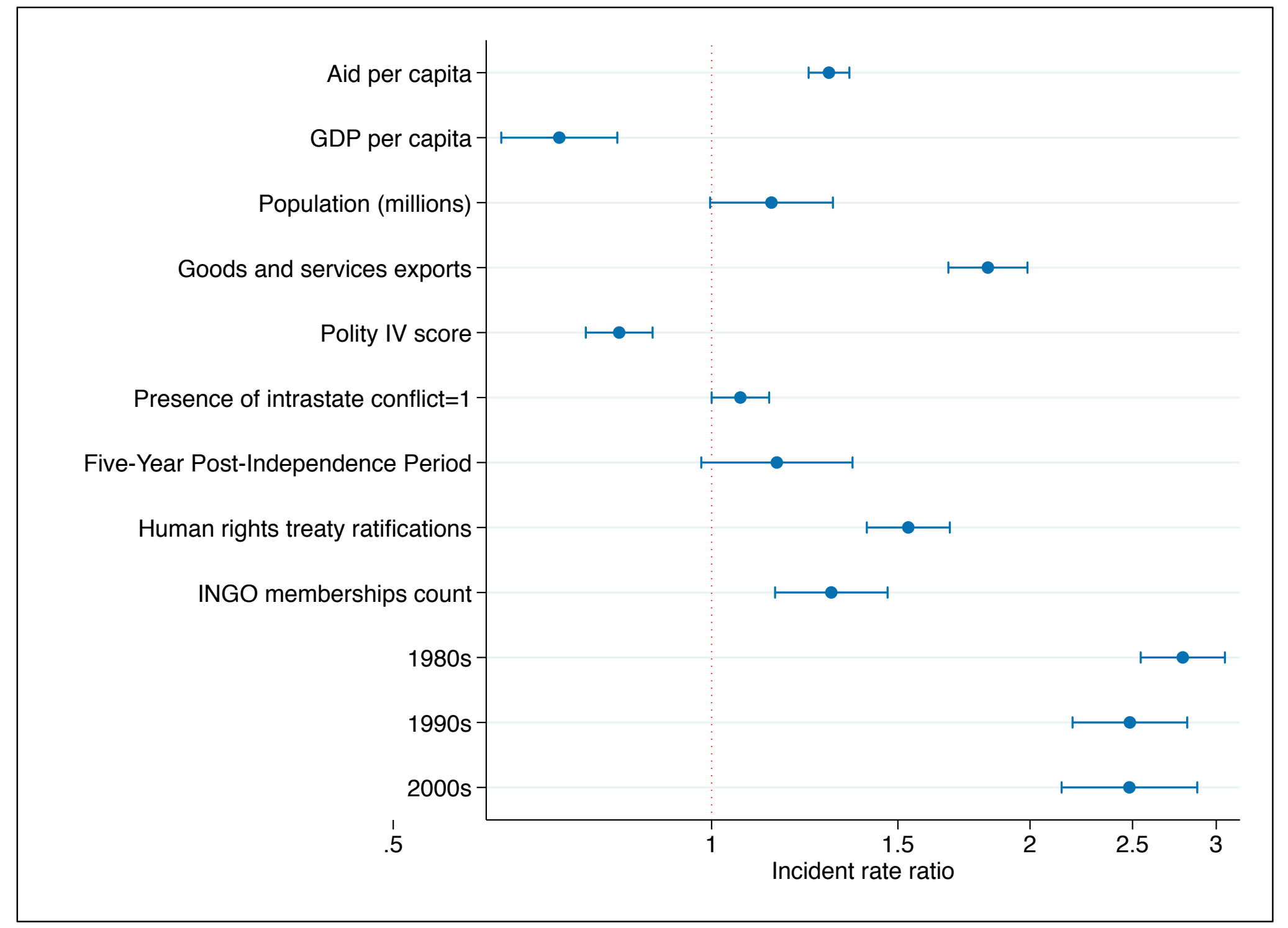




\section{Appendix 1: Descriptive Statistics - Aid Measures}

\begin{tabular}{|c|c|c|c|c|c|c|}
\hline & \multicolumn{4}{|c|}{$\underline{\text { AID INDGREE NETWORK CENTRALITY }}$} & \multicolumn{2}{|c|}{$\underline{A I D}$ PER CAPITA } \\
\hline & $\min$ & mean & median & $\max$ & mean & median \\
\hline Afghanistan & 12 & 13.5 & 13.5 & 15 & 16.3 & 16.3 \\
\hline Albania & 7 & 20.4 & 22 & 25 & 83 & 88.1 \\
\hline Algeria & 9 & 15 & 14 & 27 & 12.6 & 11.4 \\
\hline Angola & 15 & 20.2 & 21 & 23 & 28.1 & 26.1 \\
\hline Argentina & 9 & 16.5 & 16.5 & 25 & 4 & 3 \\
\hline Armenia & 15 & 19.9 & 20.5 & 23 & 69.3 & 68.7 \\
\hline Azerbaijan & 14 & 18.1 & 18 & 22 & 22.3 & 21.3 \\
\hline Bahrain & 0 & 3.8 & 4 & 7 & 254.6 & 109.4 \\
\hline Bangladesh & 18 & 20.6 & 20.5 & 25 & 17.6 & 18.4 \\
\hline Benin & 11 & 15.8 & 16 & 21 & 47.6 & 46.7 \\
\hline Bhutan & 9 & 14.7 & 15 & 17 & 110.4 & 117.8 \\
\hline Bolivia & 12 & 17.8 & 19 & 22 & 77.5 & 76.9 \\
\hline Botswana & 11 & 15.8 & 16 & 18 & 113.2 & 125.5 \\
\hline Brazil & 11 & 18.3 & 19.5 & 26 & 1.7 & 1.7 \\
\hline Burkina Faso & 12 & 17.6 & 19 & 22 & 47.1 & 47.1 \\
\hline Burundi & 10 & 17.1 & 17 & 23 & 42.7 & 48.4 \\
\hline Cambodia & 19 & 22.4 & 22.5 & 25 & 33.9 & 32.7 \\
\hline Cameroon & 11 & 17.5 & 18 & 23 & 42.9 & 39.7 \\
\hline Central African Rep. & 9 & 13.8 & 13 & 21 & 60.1 & 62.8 \\
\hline Chad & 10 & 14.8 & 14.5 & 23 & 39.2 & 36.8 \\
\hline Chile & 8 & 16.8 & 17 & 24 & 6 & 4.7 \\
\hline China & 14 & 20.5 & 20.5 & 26 & 1.7 & 1.5 \\
\hline Colombia & 11 & 18 & 18.5 & 26 & 6.9 & 5.5 \\
\hline Comoros & 5 & 8.3 & 8 & 11 & 122.1 & 124 \\
\hline Congo, Rep. & 8 & 14.4 & 14 & 20 & 85.1 & 77.7 \\
\hline Costa Rica & 9 & 14.8 & 15 & 18 & 50.1 & 39.1 \\
\hline Cote d'Ivoire & 10 & 16.2 & 16 & 23 & 42.2 & 42.5 \\
\hline Croatia & 8 & 19.9 & 21.5 & 26 & 20.6 & 24.6 \\
\hline Cuba & 8 & 14.8 & 14 & 26 & 7.1 & 6.5 \\
\hline Cyprus & 0 & 8.2 & 9 & 11 & 115.9 & 86.3 \\
\hline Djibouti & 7 & 10.8 & 11 & 15 & 164.7 & 124.6 \\
\hline Dominican Republic & 10 & 14.5 & 14.5 & 20 & 19.9 & 17.7 \\
\hline Ecuador & 11 & 17.9 & 18.5 & 23 & 19.8 & 20.7 \\
\hline Egypt & 16 & 19.8 & 20 & 26 & 59.3 & 49.2 \\
\hline El Salvador & 10 & 18 & 20 & 26 & 60.6 & 54.1 \\
\hline Equatorial Guinea & 0 & 9.2 & 10 & 13 & 92.6 & 63.8 \\
\hline Eritrea & 18 & 20.2 & 20 & 23 & 51.2 & 52.7 \\
\hline Ethiopia & 17 & 19.2 & 19 & 21 & 21.9 & 23.4 \\
\hline Fiji & 7 & 10.6 & 11 & 13 & 80.3 & 76.2 \\
\hline Gabon & 4 & 9.4 & 9.5 & 13 & 118.5 & 127.5 \\
\hline Gambia & 11 & 16.3 & 16.5 & 20 & 96.9 & 100.8 \\
\hline Georgia & 16 & 21.5 & 21.5 & 26 & 52.1 & 52.7 \\
\hline Ghana & 14 & 19.1 & 20 & 25 & 38.6 & 38.8 \\
\hline Guatemala & 11 & 17 & 19 & 22 & 24.7 & 23.5 \\
\hline Guinea & 15 & 17.7 & 18 & 21 & 47.9 & 48.9 \\
\hline Guinea-Bissau & 10 & 15.5 & 16 & 19 & 119.7 & 121.9 \\
\hline
\end{tabular}




\begin{tabular}{|c|c|c|c|c|c|c|}
\hline Guyana & 7 & 10.8 & 11 & 14 & 125.8 & 117.9 \\
\hline Haiti & 15 & 18.9 & 19 & 23 & 40 & 31.4 \\
\hline Honduras & 10 & 17 & 17 & 23 & 77.7 & 73.4 \\
\hline India & 16 & 19.3 & 19 & 27 & 3.2 & 3.1 \\
\hline Indonesia & 13 & 18.2 & 18 & 25 & 9.7 & 10.3 \\
\hline Iran & 6 & 14.9 & 14 & 28 & 2.1 & 2.1 \\
\hline Israel & 0 & 10.4 & 11 & 16 & 469.8 & 439.8 \\
\hline Jamaica & 9 & 14.6 & 15 & 18 & 95.3 & 116.6 \\
\hline Jordan & 10 & 17.2 & 18 & 23 & 348.4 & 205.2 \\
\hline Kenya & 16 & 20.4 & 20.5 & 27 & 33.7 & 33.9 \\
\hline Korea & 0 & 10.8 & 12 & 15 & 3.8 & 0.4 \\
\hline Kuwait & 0 & 3.5 & 3 & 9 & 4.4 & 3.8 \\
\hline Kyrgyz Republic & 16 & 20.8 & 21 & 24 & 47.3 & 46.4 \\
\hline Laos & 11 & 18.1 & 19 & 24 & 45.7 & 47.6 \\
\hline Lebanon & 17 & 23.3 & 26 & 27 & 84.7 & 55.8 \\
\hline Lesotho & 12 & 15.8 & 16 & 19 & 81.7 & 88 \\
\hline Liberia & 9 & 14.8 & 14 & 24 & 59.9 & 59.5 \\
\hline Libya & 0 & 8.5 & 9 & 16 & 1.8 & 1.1 \\
\hline Macedonia & 13 & 20.4 & 22 & 24 & 87.1 & 92.5 \\
\hline Madagascar & 9 & 16 & 16 & 22 & 37.2 & 35.3 \\
\hline Malawi & 12 & 18.8 & 20 & 25 & 45.1 & 41 \\
\hline Malaysia & 12 & 15.5 & 15 & 19 & 12.4 & 12.1 \\
\hline Mali & 11 & 17.2 & 17 & 23 & 55.2 & 55.2 \\
\hline Mauritania & 10 & 15.3 & 15.5 & 20 & 167.2 & 148.7 \\
\hline Mauritius & 10 & 13 & 13 & 16 & 53 & 51.2 \\
\hline Mexico & 9 & 17.5 & 18 & 23 & 2.5 & 2.5 \\
\hline Moldova & 19 & 23.2 & 23.5 & 26 & 29.8 & 29.7 \\
\hline Mongolia & 0 & 15.8 & 19.5 & 26 & 53.6 & 66.8 \\
\hline Morocco & 10 & 16.1 & 16 & 23 & 38.6 & 27.7 \\
\hline Mozambique & 16 & 21.6 & 22 & 27 & 63.9 & 59.2 \\
\hline Namibia & 21 & 22.6 & 23 & 24 & 97.4 & 103.4 \\
\hline Nepal & 13 & 19.7 & 20 & 25 & 20.5 & 20.1 \\
\hline Nicaragua & 8 & 18.3 & 20 & 24 & 107.7 & 92.6 \\
\hline Niger & 12 & 16.2 & 17 & 23 & 50.2 & 50 \\
\hline Nigeria & 12 & 18.9 & 19.5 & 26 & 5.2 & 1.8 \\
\hline Oman & 3 & 6.4 & 6 & 10 & 97.8 & 30.3 \\
\hline Pakistan & 15 & 18.7 & 17 & 25 & 14.9 & 13.5 \\
\hline Panama & 9 & 12.4 & 12 & 16 & 26.1 & 17.8 \\
\hline Papua New Guinea & 9 & 14.2 & 15 & 17 & 124.1 & 114.6 \\
\hline Paraguay & 9 & 14.2 & 14.5 & 19 & 24.7 & 23.4 \\
\hline Peru & 16 & 20.2 & 20 & 25 & 20.5 & 18.6 \\
\hline Philippines & 14 & 19.3 & 20 & 22 & 14.2 & 13.4 \\
\hline Rwanda & 11 & 18.6 & 19 & 26 & 59.8 & 53.5 \\
\hline Saudi Arabia & 0 & 6.7 & 7 & 10 & 2.1 & 1.2 \\
\hline Senegal & 13 & 18.5 & 19 & 25 & 86.2 & 86.8 \\
\hline Sierra Leone & 14 & 18.9 & 18.5 & 25 & 42.3 & 37.8 \\
\hline Singapore & 0 & 7.6 & 9 & 11 & 12.7 & 12 \\
\hline Slovenia & 0 & 9.7 & 11 & 18 & 30.5 & 27.6 \\
\hline Solomon Islands & 5 & 8.4 & 8 & 15 & 186.2 & 168.1 \\
\hline Somalia & 11 & 16.2 & 16 & 21 & 103.4 & 97.4 \\
\hline South Africa & 21 & 23.8 & 24 & 27 & 11.4 & 11.7 \\
\hline Sri Lanka & 16 & 19.3 & 18 & 27 & 39.9 & 44.1 \\
\hline Sudan & 15 & 20.9 & 21 & 28 & 36 & 39.5 \\
\hline Swaziland & 10 & 13.6 & 14 & 16 & 71.3 & 70 \\
\hline
\end{tabular}




\begin{tabular}{lrccccc} 
Syria & 9 & 14.1 & 13 & 21 & 102.1 & 32.1 \\
Tajikistan & 15 & 19.1 & 20 & 23 & 22.1 & 21.2 \\
Tanzania & 20 & 22.6 & 22 & 26 & 39.3 & 35.3 \\
Thailand & 15 & 19.4 & 19.5 & 25 & 11.1 & 13.8 \\
Togo & 12 & 15 & 14.5 & 23 & 46.5 & 50 \\
Trinidad \& Tobago & 6 & 8.9 & 9 & 11 & 10.1 & 8.9 \\
Tunisia & 10 & 14.5 & 13.5 & 19 & 50.4 & 43.8 \\
Turkey & 6 & 12.8 & 13 & 18 & 10.5 & 6 \\
Turkmenistan & 7 & 11.9 & 12 & 18 & 7 & 6.5 \\
Uganda & 10 & 19.8 & 20 & 26 & 29.3 & 31.7 \\
Ukraine & 24 & 24 & 24 & 24 & 8.3 & 8.3 \\
United Arab Emirates & 0 & 3.6 & 4 & 6 & 16.1 & 4.6 \\
Uruguay & 7 & 14.3 & 14.5 & 20 & 11.9 & 9.1 \\
Uzbekistan & 11 & 18.5 & 20 & 23 & 5.6 & 6 \\
Venezuela & 6 & 14.2 & 14 & 24 & 1.8 & 1.8 \\
Zambia & 16 & 19.8 & 19 & 25 & 87.2 & 77.5 \\
Zimbabwe & 17 & 21 & 21 & 25 & 36.9 & 40 \\
& & & & & & \\
\hline TOTAL & 0 & 16 & 16 & 28 & 56.6 & 34.6 \\
\hline
\end{tabular}




\section{REFERENCES}

Acharya, Arnab, Ana Teresa Fuzzo de Lima, and Mick Moore. 2006. "Proliferation and fragmentation: Transactions costs and the value of aid." Journal of Development Studies 42(1):1-21.

Alesina, A., and D. Dollar. 2000. "Who Gives Foreign Aid to Whom and Why?" Journal of Economic Growth 5(1):33-63.

Annen, K., and S. Kosempel. 2009. "Foreign Aid, Donor Fragmentation, and Economic Growth." The BE Journal of Macroeconomics 9(1):33.

Barrett, Deborah, and Amy Ong Tsui. 1999. "Policy as Symbolic Statement: International Response to National Population Policies." Social Forces 78(1):213-33.

Beckfield, Jason. 2003. "Inequality in the world polity: The structure of international organization." American Sociological Review 68(3):401-24.

-. 2008. "The dual world polity: fragmentation and integration in the network of intergovernmental organizations." Social Problems 55(3):419-42.

Bermeo, Sarah Blodgett. 2011. "Foreign Aid and Regime Change: A Role for Donor Intent." World Development 39(11):2021-31.

Brown, Stephen, and Liam Swiss. 2013. "The Hollow Ring of Donor Commitment: Country Concentration and the Decoupling of Aid Effectiveness Norms from Donor Practice." Development Policy Review 31(6):737-55.

Carment, David, Yiagadeesen Samy, and Stewart Prest. 2008. "State Fragility and Implications for Aid Allocation: An Empirical Analysis." Conflict Management and Peace Science 25(4):349-73. 
Clark, Rob. 2010. "Technical and Institutional States Loose Coupling in the Human Rights Sector of the World Polity." Sociological Quarterly 51(1):65-95.

Clark, Rob, and Jason Hall. 2011. "Migration, International Telecommunications, and Human Rights." Sociological Forum 26:870-96.

Cole, Wade M. 2012. "Human Rights as Myth and Ceremony? Reevaluating the Effectiveness of Human Rights Treaties, 1981-2007." American Journal of Sociology 117(4):1131-71. -. 2013. "Strong Walk and Cheap Talk: The Effect of the International Covenant of Economic, Social, and Cultural Rights on Policies and Practices." Social Forces 92(1):165-94.

Dreher, Axel, Peter Nunnenkamp, and Rainer Thiele. 2011. "Are 'New' Donors Different? Comparing the Allocation of Bilateral Aid Between nonDAC and DAC Donor Countries." World Development 39(11):1950-68.

Fallon, K.M., L. Swiss, and J. Viterna. 2012. "Resolving the Democracy Paradox: Democratization and Women's Legislative Representation in Developing Nations, 19752009." American Sociological Review 77(3):380-408.

Feeny, Simon, and Mark McGillivray. 2009. "Aid allocation to fragile states: Absorptive capacity constraints." Journal of International Development 21(5):618-32.

Fejerskov, Adam Moe. 2015. "From Unconventional to Ordinary? The Bill and Melinda Gates Foundation and the Homogenizing Effects of International Development Cooperation." Journal of International Development 27(7):1098-112.

Gelman, Andrew. 2008. "Scaling regression inputs by dividing by two standard deviations." Statistics in medicine 27(15):2865-73.

Gerring, J, SC Thacker, and C Moreno. 2005. "Centripetal democratic governance: A theory and global inquiry." American Political Science Review 99(04):567-81. 
Gleditsch, NP, P Wallensteen, M Eriksson, M Sollenberg, and H Strand. 2002. "Armed conflict 1946-2001: A new dataset." Journal of Peace Research 39(5):615-37.

Hafner-Burton, Emilie, and Kiyoteru Tsutsui. 2005. "Human Rights in a Globalizing World: The Paradox of Empty Promises." American Journal of Sociology 110(5):1373-411.

Heston, A., R. Summers, and B. Aten. 2011. "Penn world tables 7.0." Available from pwt. econ. upenn. edu.

Hout, Wil. 2002. "Good Governance and Aid: Selectivity Criteria in Development Assistance." Development and Change 33(3):511-27.

-.2007. Politics of Aid Selectivity, The: Good Governance Criteria in World Bank, US and Dutch Development Assistance. London: Routledge.

—. 2012. "The Anti-Politics of Development: donor agencies and the political economy of governance." Third World Quarterly 33(3):405-22.

Hughes, M.M., L. Peterson, J.A. Harrison, and P. Paxton. 2009. "Power and Relation in the World Polity: The INGO Network Country Score, 1978-1998." Social Forces 87(4):1711-42.

Jackson, J.T. 2005. The globalizers: development workers in action. Baltimore, MD: Johns Hopkins University Press.

Kilby, Christopher. 2011. "What Determines the Size of Aid Projects?" World Development 39(11):1981-94.

Knack, Stephen, and Aminur Rahman. 2007. "Donor fragmentation and bureaucratic quality in aid recipients." Journal of Development Economics 83(1):176-97.

Lumsdaine, David Halloran. 1993. Moral vision in international politics : the foreign aid regime, 1949-1989. Princeton, N.J.: Princeton University Press. 
Marshall, M.G., K. Jaggers, and T.R. Gurr. 2009. "Polity IV Project: Political Regime Characteristics and Transitions, 1800-2009." Polity IV.

Meyer, J.W., J. Boli, George M. Thomas, and Francisco O. Ramirez. 1997. "World society and the nation-state." The American Journal of Sociology 103(1):144-81.

Moore, S, E Eng, and M Daniel. 2003. "International NGOs and the role of network centrality in humanitarian aid operations: A case study of coordination during the 2000 Mozambique floods." Disasters 27(4):305-18.

Morgenthau, Hans. 1962. "A Political Theory of Foreign Aid." The American Political Science Review 56(2):301-09.

Opeskin, B.R. 1996. "The Moral Foundations of Foreign Aid." World Development 24(1):21-44.

Paxton, Pamela, Melanie M Hughes, and Nicholas Reith. 2015. "Extending the INGO Network Country Score, 1950-2008." Sociological Science 2:287-307.

Peterson, L.P. 2011. "Foreign Aid, INGOs and Development: A Cross-National and Longitudinal Examination of the Global Development System." Pp. 226 in Department of Sociology. Columbus, OH: The Ohio State University.

Peterson, Lindsey. 2014. "A Gift You Can't Refuse? Foreign Aid, INGOs and Development in the World Polity." Studies in Emergent Order 7:81-102.

Rabe-Hesketh, S., and A. Skrondal. 2008. Multilevel and longitudinal modeling using Stata: Stata Corp.

Schofer, Evan, and Wesley Longhofer. 2011. "The Structural Sources of Association." American Journal of Sociology 117(2):539-85. 
Swiss, Liam. 2011. "Security Sector Reform and Development Assistance: Explaining the Diffusion of Policy Priorities Among Donor Agencies." Qualitative Sociology 34(2):37193.

- . 2012. "The Adoption of Women and Gender as Development Assistance Priorities: An Event History Analysis of World Polity Effects." International Sociology 27(1):96-119.

-. 2016. "A Sociology of Foreign Aid and the World Society." Sociology Compass 10(1):65-73.

—. Forthcoming. "World Society and the Global Foreign Aid Network." Sociology of Development.

Swiss, Liam, and Stephen Brown. 2015. "The aid orphan myth." Third World Quarterly $36(2): 240-56$.

Swiss, Liam, and Wesley Longhofer. 2016. "Membership has its privileges: Shared international organizational affiliation and foreign aid flows, 1978-2010." Social Forces 94(4):176993.

Themnér, L., and P. Wallensteen. 2011. "Armed conflict, 1946-2010." Journal of Peace Research 48(4):525-36.

Wilson, Sven E. 2011. "Chasing Success: Health Sector Aid and Mortality." World Development 39(11):2032-43.

Woods, Ngaire. 2008. "Whose aid? Whose influence? China, emerging donors and the silent revolution in development assistance." International Affairs 84(6):1205-21.

World Bank. 2010. World development indicators. Washington DC: World Bank.

Wotipka, Christine M., and Francisco O. Ramirez. 2008. "World Society and Human Rights: An Event History Analysis of the Convention on the Elimination of All Forms of Discrimination Against Women." Pp. 303-43 in The Global Diffusion of Markets and 
Democracy, edited by B.A. Simmons, F. Dobbin, and G. Garrett. Cambridge: Cambridge University Press. 